\title{
Bone mineral density improvement after one year of treatment with etanercept in patients with juvenile idiopathic arthritis G Susic*1, R Stojanovic ${ }^{1}$, N Damjanov ${ }^{1}$, J Vojinovic ${ }^{2}$ and G Vijatov ${ }^{3}$
}

\author{
Address: ${ }^{1}$ Institute of rheumatology, Belgrade, Serbia, ${ }^{2}$ Clinic of Pediatrics, University Clinical Center, Nis, Serbia and ${ }^{3}$ Institute for Child and \\ Youth Health Care, Novi Sad, Serbia \\ * Corresponding author
}

from I5th Paediatric Rheumatology European Society (PreS) Congress

London, UK. 14-17 September 2008

Published: 15 September 2008

Pediatric Rheumatology 2008, 6(Suppl I):P90 doi:I0.II86/I546-0096-6-SI-P90

This abstract is available from: http://www.ped-rheum.com/content/6/SI/P90

(C) 2008 Susic et al; licensee BioMed Central Ltd.

\section{Background}

Multiple risk factors are playing role in development of osteopenia in JIA. One of the most important is inflammatory nature of disease. Etanercept induces rapid and sustained suppression of JIA disease activity and could have protective effect on bone.

\section{Aim of the study}

To assess influence of etanercept on bone mineral density (BMD) in patients with JIA.

\section{Patients and methods}

In prospective study of 37 JIA pts $(26 \mathrm{~F}, 11 \mathrm{M})$, mean age 16,3 yrs. with polyarthicular course, we have assessed $\mathrm{BMD}$ and bone mineral content (BMC) by dual x-ray absorptiometry on the lumbar spine (L2-L4) before and one or two years (in 13 pts) after introduction of etanercept.

Results of osteodentometry assessment (mean value) are presented on table 1 .

After the first year of treatment we have noticed significant improvement of all ostedensitometric values. Mean value difference for $\mathrm{BMD}$, compare to baseline was $7,1 \%$ (p < $0,001)$ for $Z$ score $17,76 \%(p=0,002)$, for BMC 13,13\% $(\mathrm{p}<0,001)$ and for $\mathrm{BMD}_{\mathrm{vol}} 5 \%(\mathrm{p}<0,001)$. Bone mineral status continued to increase during the second years of treatment as well $(13 \mathrm{pts})(\mathrm{p}<0,001)$.

\section{Conclusion}

Our results demonstrated efficacy of etanercept, as TNF blocker, in improving bone mineral status and precluding of osteoporosis development in children with JIA. This beneficial effect on bone was demonstrated on the end of second year of treatment. 
Table I:

\begin{tabular}{lll}
\hline variables & baseline & after Ist year \\
\hline BMD $\left(\mathrm{g} / \mathrm{cm}^{2}\right)$ & 0,909 & 0,965 \\
$Z$ (SD) & $-1,2$ & $-0,93$ \\
$\mathrm{BMC}(\mathrm{g} / \mathrm{cm})$ & 32,68 & 36,08 \\
$\mathrm{BMD}_{\text {vol }}\left(\mathrm{g} / \mathrm{cm}^{3}\right)^{*}$ & 0,314 & 0,329 \\
\hline
\end{tabular}

Publish with Bio Med Central and every scientist can read your work free of charge

"BioMed Central will be the most significant development for disseminating the results of biomedical research in our lifetime. " Sir Paul Nurse, Cancer Research UK

Your research papers will be:

- available free of charge to the entire biomedical community

- peer reviewed and published immediately upon acceptance

- cited in PubMed and archived on PubMed Central

- yours - you keep the copyright 